\title{
GLOBAL CLASSROOM: INTERNATIONALIZATION FOR UNDERGRADUATE STUDENTS AMID THE PANDEMIC
}

\author{
Garza-Olivares X*, Cavazos-Montemayor RN and Lopez M \\ Tecnologico de Monterrey, Escuela de Medicina y Ciencias de la Salud, Mexico
}

\begin{abstract}
The international exchange for undergraduate students is a life-changing experience, an opportunity to interact with others and develop intercultural skills while learning. Nevertheless, the deficit in student participation in internationalization activities demands new formats that offer this academic practice in a virtual environment. Adjacent to this scenario, the greatest impact of the COVID-19 pandemic on higher education was face-to-face exchanges. Therefore, academic programs as Global Classroom was the only way for an international exchange amid the pandemic. The objective of this study was to assess the perceptions of the students about an implementation of a virtual international exchange shared with students from Mexico and Ecuador, focused on this contribution as an educational innovation to promote learning in multicultural and interdisciplinary skills. The study considered a quantitative approach to analyze a student's perception of the experience, and the design was descriptive and cross-sectional. The sample were 44 students enrolled in the experience in the August-December semester in 2020, 22 from Mexico and 22 from Ecuador. The instrument was made of 5 items in which the participants shared their experience regarding the different tools and activities, and their contribution to the educational objectives. Results show that the students valued the intercultural experience positively and the contribution of the different free-access educational technology tools to develop synchronous and asynchronous activities. Other disciplines and institutions can learn from this implementation to design remote educational environments that offer this internationalization experience for learners even after the pandemic.
\end{abstract}

Keywords: higher education, educational innovation, interdisciplinary education, intercultural education, pandemic adaptations, global exchange.

\section{Introduction}

Globalization and technological development have brought with them new forms of employment that require the formation of intercultural teams whose relationships are established in virtual environments. In this regard, Parrott and Jones (2018) argue that universities need to develop intercultural and communication skills in their students through innovative teaching approaches which can include virtual academic exchanges.

Especially in the last part of the XX century, higher education institutions started to emphasize the importance of academic exchanges to foster the intercultural dimension in every curriculum (Barbosa et al., 2020). However, participation in global learning experiences remains low in comparison to the enrolment, as not all students have the opportunity to strengthen these global skills through face-to- 
face exchange programs (Parrott \& Jones, 2018). Some factors that contribute to this are the cost of living abroad, the lack of agreements that regulate credit transfer, and the promotion of activities that showcase these special academic opportunities. This has led universities to develop proposals for international collaboration in virtual environments to encourage these experiences without the need for international travel.

In March 2020, the COVID-19 pandemic had a major impact on the education sector globally (Valdez-García, et.al. 2020). To implement social-distancing measures, most of the student population participated in distance education models, which was the way in which higher education institutions were able to guarantee continuity of their training (Marinoni et al., 2020; Gabriels \& Benke-Aberg, 2020). At first, the focus was on guaranteeing students' safety, and then on continuing their training momentarily. As weeks went by and the virus dissemination showed that it was not going to be resolved in the short term. Educational institutions needed to focus on the complete university experience, for example on the extracurricular activities, wellbeing and wellness initiatives, and internationalization.

Exchanges in virtual environments were an option to improve accessibility and optimize institutional and student resources to internationalization experiences. The impact of the pandemic meant that outof-the-box ideas that previously seem unrealistic, were now welcomed if it meant for students to get an integral university experience. The practice of virtual exchanges, co-teaching, and collaborative projects were more necessary than ever.

\section{Intercultural learning}

Intercultural education is a necessity in a globalized world because respect for cultural identity is essential to maintain the culture of peace and they are societies that embrace multicultural diversity from their origin (Schmelkes, 2013) or as a result of recent migrations (Castro, 2019). The United Nations Educational, Scientific and Cultural Organization (UNESCO) defines multiculturalism or cultural diversity as the characterization of a social group through distinctive spiritual, material, intellectual and emotional features (UNESCO, 2004).

Globalization brings on a multicultural context, which is the convergence of people with different cultural origins, but it requires a recognition of equality to consider it an intercultural context. Interculturality assumes that there are links between different cultural groups based on respect and equality (Schmelkes, 2013; Lima et al., 2020).

Developing competencies that lead to better interactions with others and improve respect for cultural differences should be one goal of higher education, especially in health professions such as psychology (Patterson et al., 2018; Veliz-Rojas et al., 2019). According to the American Psychological Association (APA) the intercultural skills are essential in psychology professionals and need to be included in the training of undergraduate students (APA, 2017).

Intercultural competence makes it possible to identify and respect the cultural heritage, historical and socio-political context of each person's group of origin (Chappell, 2014). Interactions with other cultures foster attitudes of empathy and recognition of diversity; for example, being aware that skin 
color has been an identity element that has historically marked inequalities between cultural groups (Chappell, 2014; Patterson et al., 2018).

Despite the recognition of the need to develop intercultural competence, it is not an easy task, among the difficulties to develop it is the variability of models the difficulty to measure it, and the plurality of elements that compose it (Patterson, Papa, Reveles \& Domenech, 2018). Schmelkes (2013) and Castro (2019) emphasize that intercultural education requires a sociopolitical context of democracy and the desire to maintain multiculturalism present in society, sometimes even though there is such recognition, the fear of losing a unified identity persists (Schmelkes, 2013). In this sense, it is still pertinent to directly address intercultural education as an educational goal.

Peñalva Vélez and Leiva Olivencia (2019) describe that the qualities of teachers to transmit intercultural education, such as the positive attitude towards cultural diversity and the recognition of their own culture in the depth of how it influences their personal worldview.

The dialogue between students from different cultural contexts has a positive impact on the development of critical thinking skills, students can make conceptual inferences from educational activities, analyze and interpret the context that poses the problem to be solved (López-Ruiz et al., 2021). Critical thinking is a cognitive process necessary for decision-making competence because it involves the reasoning process that leads to choosing action now, but also its projection to the future consequences (Muñeton et al., 2017).

Another of the skills that are developed directly with intercultural education is teamwork, collaborating with other students from different cultural contexts reinforces not only empathy but also shared responsibility to develop a proposal for action (Murdoch-Kitt et al., 2020).

Teamwork is also developed through activities within an interdisciplinary framework which is why it can go hand in hand with intercultural education. As Veliz-Rojas, Bianchetti-Saavedra and SilvaFernández (2019) emphasize, achieving a cultural education exchange must be carried out from an interdisciplinary and global approach.

\section{Global Classroom}

Each university had a specific proposal for virtual academic exchanges, the model in Tecnologico de Monterrey was named Global Classroom, organized by the International Affairs office that aims to coordinate two courses of different universities into a digital environment. The focus is promoting learning in multicultural environments through collaborative activities, teachers and students have the opportunity to exchange ideas and activities. This allows them to establish a meaningful dialogue among different cultures, break down stereotypes and build academic collaboration networks.

After reviewing the existing models of intercultural education, the present work can be placed in a model centered on cultural pluralism, because the activities designed for this educational experience were focused on promoting communication and dialogue regarding diversity (Castro, 2019).

This Global Classroom implementation focused on a shared virtual class, based on the Collaborative Online International Learning (COIL) model in higher education. This model was developed by New York University in 2006 and has since been maintained as a pedagogical strategy to promote 
internationalization and intercultural learning through virtual environments. The distinctive elements of the COIL model are multicultural teams, activities, and spaces for open dialogue about interests, an atmosphere of respect for cultural backgrounds, and a common problem-solving approach (VeraMarquez et al., 2019).

The use of technology for interaction in the teaching-learning process was essential, the selection of technology tools to carry out the educational activities and the interaction between the students, were chosen after analyzing the relevance of the challenge and the favorable impact on the aim of the experience (López Cabrera et al., 2019), as well the familiarity of both teachers and students in using these tools by means of asynchronous or synchronous activities (Vera-Marquez et al., 2019).

Securing the internationalization experience for undergraduate students amid the pandemic was one of the primary motivations to implement this experience between Mexico and Ecuador thus the promotion of intercultural learning. In addition, the educational experience was designed considering getting involved in interdisciplinary practice. Students from both countries came from different undergraduate programs fields such as psychology, anthropology, business, marketing, and industrial design, enrolled in Social Psychology class (Mexico) and Gender and Sexuality class (Ecuador). The adaptation to the COIL model of this implementation, Global Classroom, is presented in figure 1.

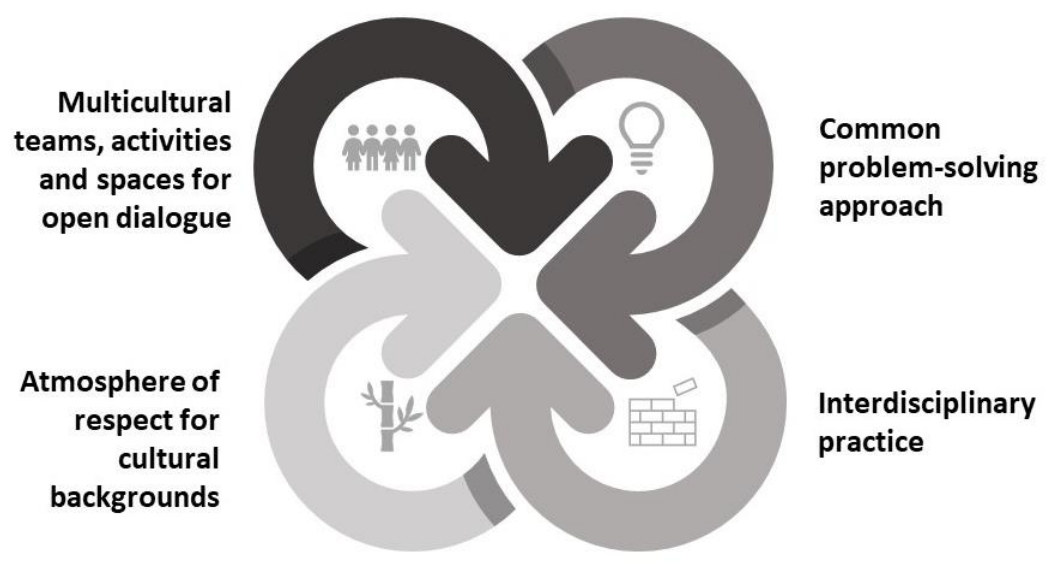

Figure 1: Model of Global Classroom amid the pandemic

The value proposition of this model relies in interdisciplinarity. The complexity of many of the current problems that have distinct elements in their constitution or are multifactorial requires an integrated vision from different points of view, practices, and disciplinary perspectives. In this sense, it is increasingly common to find terms of multidisciplinarity, interdisciplinarity, or transdisciplinarity (Valencia García, 2020). Nevertheless, they are not synonymous, each concept implies a different position of interaction and involvement between disciplines (Fernández et al., 2012; Kiewt \& Barrantes, 2018). Professional training is regularly done in a specific disciplinary framework, interacting outside those limits is one goal of transdisciplinary (Kiewt \& Barrantes, 2018). Achieving interdisciplinarity in learners of the XXI century has become a necessity (Meeuwissen et al., 2020).

In this global exchange program, the aim was to work collaboratively on a common academic project in both courses, specifically the design of campaigns to promote health and human dignity. At the 
same time, this academic experience allowed that students understand the cultural context of Mexico and Ecuador and the social contexts as sexual and gender diversity.

Consequently, the purposes of the present study were to assess the implementation of a virtual international exchange as an educational innovation for intercultural and interdisciplinary skills. Particularly on understanding its impact on the transversal skills, as critical thinking, communication, teamwork and decision-making.

\section{Method}

This study considered a quantitative approach, with an exploratory descriptive design. The sample were 44 students enrolled in the experience in the August-December semester in 2020, from which 22 were participants from Mexico and 22 from Ecuador. The participation of the students was voluntary, which they expressed through the signing of the informed consent after the verbal and written description of the research.

The instrument was made of 5 items in which the participants shared their experience regarding the different tools and activities, and their contribution to the educational objectives. Three of the items were presented in a 5-point Likert scale, varying from 1 strongly disagree to strongly agree (Table 1). And two of them were open responses, the remaining two were in an open format where the most common responses regarding the skills developed in the academic experience were analyzed.

The data analysis strategy considered as descriptive statistics, mean and standard deviation of the different items. The statistical analysis of the results was carried out with SPSS 21 software. The open-ended questions were analyzed using content analysis by the research team.

\section{Results}

The educational experience in Global Classroom made possible academic continuity. The collaboration in both courses allowed the development of multiculturalism as the ability to dimension cultural differences between social groups. The measurement of this academic experience was done by exploring the students' perception of the communication tools and number of activities.

The students' perception is presented in table 1 . The key elements of the implementation received a favorable valuation: communication tools, number of activities and multiculturalism in the experience. The most favorable response was obtained in item 3) Global Classroom was a multicultural experience with a mean of 4.84 The lowest perception was obtained in item 2) "The volume of activities facilitated the understanding of the topics and objective of the exchange" with a mean of 4.52 . 
The volume of activities facilitated the understanding of the topics and objective of the exchange.

In the items in open question format, specifically 4) "What was the most relevant part of the experience?" and 5) "What are your personal and professional learnings from experience", the 44 students showed 146 responses. Those that were grouped into 5 categories the most relevant of the experience was Dialogue $28.77 \%$ and Cultural diversity $25.34 \%$, and then followed Critical thinking $17.12 \%$ and Teamwork $17.12 \%$. The one that was mentioned the least was acceptance of differences $11.64 \%$.

\section{Discussion}

Academic continuity in times of the COVID-19 pandemic has been a challenge for higher education, the impact on international student mobility was significant. About $89 \%$ of higher education institutions were affected with cancellations of international exchanges; however, the contingency plans implemented allowed strengthening and developing different innovations for interaction with other students from different cultural backgrounds which generated a $60 \%$ increase in online academic exchanges (Marinoni et al., 2020).

This educational innovation allowed a multicultural experience, according to the responses of participants in this study evaluated the Global Classroom experience. The selection of distance communication tools as Padlet, Zoom, Google sites were valued positively thanks to the fact that the selection recommendations were followed: accessibility, relevance, and familiarity (Vera-Marquez et al., 2019; López Cabrera et al., 2019). An ethical principle was to ensure equals access to online learning tools, respecting the diversity of contexts (Gabriels \& Benke-Aberg, 2020).

We believe that although the Acceptance of differences was the topic with the lowest mentions in the description of learnings, as some authors named intercultural education and interdisciplinarity require effort and training, besides the motivation to develop empathy (Patterson et al., 2018; Meeuwissen et al., 2020).

\section{Conclusion}

The continuity of higher education in the COVID-19 pandemic requires strengthening the learning, communication and collaboration environments in remote learning teams. Emphasizing the interdisciplinary and intercultural education requires an open dialogue with other cultures, maintaining a context of respect for cultural or disciplinary origins. Learning experiences that incorporate the intercultural dimension increase students' motivation to interact with other cultures 
and teachers' commitment to the course they teach and to more innovative teaching methods (Barbosa et al., 2020; Patterson et al., 2018).

Some limitations of the study include a limited number of students, as with other studies of this nature whose emphasis is on a specific educational experience implemented, the participants in the Global Classroom were few. Another limitation was related to the method used, as a quantitative design only explored some dimensions of student perception to evaluate the entire experience. Further studies may incorporate a qualitative phase into the methodology. Additionally, it is important to include instruments that allow the comparison with similar experiences and include validated instruments to explore each of the competencies of interculturality, critical thinking, assertive communication and teamwork among others.

Academic exchange programs in virtual environments like Global Classroom are more necessary than ever, keeping them as a permanent educational experience in academic training will favor greater access to intercultural experiences and thus an equitable development of these skills.

\section{Acknowledgments}

The authors would like to acknowledge the financial support of Writing Lab, Institute for the future of education, Tecnologico de Monterrey, Mexico, in the production of this work.

\section{References}

American Psychological Association [APA]. (2017). Multicultural guidelines: An ecological approach to context, identity, and intersectionality. http://www.apa.org/

Barbosa, B., Santos, C., \& Prado-Meza, C. (2020). There is no one way to internationalization at home: Virtual mobility and student engagement through formal and informal approaches to curricula. Revista Lusófona De Educação, 47(47) Retrieved from https://0-search-proquest-com.bibliotecails.tec.mx/scholarly-journals/there-is-no-one-way-internationalization-athome/docview/2438998662/se-2?accountid=11643

Castro, C. (2019). Los modelos de educación multicultural e intercultural. Una revisión necesaria desde una sociedad diversa. Revista Amauta, 17(33), 87-104. http://dx.doi.org/10.15648/am.33.2019.7

Chappell, CH. (2014) Evaluating the Effectiveness of an Undergraduate Multicultural Course. Psychology Learning and Teaching, 13(3) www.wwwords.co.uk/PLAT

Fernández, V., Lorieto, A., Repetto, L., Vienni, B., von Sanden, C., \& Cruz, P. (2012) Campos visuales : ecología y sociedad. Udelar. Espacio Interdisciplinario. Retrieved from: https://hdl.handle.net/20.500.12008/7406

Gabriels, W. \& Benke-Aberg, R., (2020). Student Exchanges in Times of Crisis - Research report on the impact of COVID-19 on student exchanges in Europe. Erasmus Student Network AISBL. Retrieved from: https://www.krasp.org.pl/resources/upload/Inne_dokumenty_KRASP/KoronawirusKominikaty/Student\%20Exchanges\%20in\%20Times\%20of\%20Crisis\%20-

$\%$ 20ESN\%20research\%20report\%20April\%202020(1).pdf

Kiewt, L. \& Barrantes, A. (2018) Comunidades Epistémicas: Una apuesta inter y transdisciplinaria en la Universidad Nacional, Costa Rica. Inter/Transdisciplinariedad, 5(13). http://climacom.mudancasclimaticas.net.br/?p=9963

Lima, C., Bastos, R. \& Varvakis, G. (2020). Digital learning platforms: an integrative review to support internationalization of higher education. Educação em Revista, 36, https://doi.org/10.1590/0102-4698232826 
López-Cabrera, V., Hernandez-Rangel, E., Mejía Mejía, G. \& Cerano Fuentes, J. (2019) Factores que facilitan la adopción de tecnología educativa en escuelas de medicina. Educación Médica, 20(1), 3-9, https://doi.org/10.1016/j.edumed.2017.07.006

López-Ruiz, C., Flores-Flores, R., Galindo-Quispe, A. \& Huayta-Franco, Y. (2021) Pensamiento crítico en estudiantes de educación superior: una revisión sistemática. Revista Innova Educación, 3(2), 374-385. https://doi.org/10.35622/j.rie.2021.02.006

Meeuwissen, S., Gijselaers, W., Wolfhagen, I., \& Egbrink, E. (2020) Working beyond disciplines in teacher teams: teachers' revelations on enablers and inhibitors, Perspect Med Educ, 10, 33-40 https://doi.org/10.1007/s40037-020-00644-7

Stephanie N.E. Muñeton, G., Ruiz-Martínez, A. \& Loaiza, O. (2017) Toma de decisiones. Explicaciones desde la ciencia aplicada del comportamiento. Espacios, 38(13), 1. https://revistaespacios.com/a17v38n13/17381310.html

Marinoni, G., Van't Land, H., \& Jensen, T. (2020) The Impact of COVID-19 on Higher Education Around the World, IAU Global Survey Report. Retrieved from https://www.iauaiu.net/IMG/pdf/iau_covid19_and_he_survey_report_final_may_2020.pdf

Murdoch-Kitt, K., Emans, D., and Oewel, B. (2020) Designing Six Dimensions of Intercultural Teamwork: A next-gen challenge in co-creation processes, in Boess, S., Cheung, M. and Cain, R. (eds.), Synergy - DRS International Conference 2020, 11-14 August, Held online. https://doi.org/10.21606/drs.2020.398

Organización de las Naciones Unidas para la Educación, la Ciencia y la Cultura (2004). Declaración universal sobre la diversidad cultural. Organización de las Naciones Unidas para la Educación, la Ciencia y la Cultura.

Parrott S. \& Jones S. (2018) Virtual Mobility: Flipping the Global Classroom Through a Blended Learning Opportunity. In: Hall T., Gray T., Downey G., Singh M. (eds) The Globalisation of Higher Education. Palgrave Macmillan, Cham. https://0-doi-org.biblioteca-ils.tec.mx/10.1007/978-3-31974579-4_10

Patterson, C. A., Papa, L. A., Reveles, A. K., \& Domenech Rodríguez, M. M. (2018). Undergraduate student change in cultural competence: Impact of a multicultural psychology course. Scholarship of Teaching and Learning in Psychology, 4(2), 81-92. https://doi.org/10.1037/st10000108

Peñalva Vélez, A., \& Leiva Olivencia, J.J. (2019). Metodologías cooperativas y colaborativas en la formación del profesorado para la interculturalidad. Tendencias Pedagógicas, 33, 37-46. doi:10.15366/tp2019.33.003

Schmelkes, S. (2013). Educación para un México intercultural. Sinéctica, (40), 01-12. http://www.scielo.org.mx/scielo.php?script=sci_arttext\&pid=S1665-

109X2013000100002\&lng=es\&tlng=es.

Valencia García, G. (2020). El CEIICH: la interdisciplina como acto dialógico. Revista Mexicana de Sociología, http://dx.doi.org/10.22201/iis.01882503p.2020.0.60007

Valdez-García, J., López Cabrera, M., Jiménez Martínez, M., Díaz Elizondo, J., Dávila Rivas, J. \& Olivares Olivares, S. (2020) Me preparo para ayudar: respuesta de escuelas de medicina y ciencias de la salud ante COVID-19, Investigación en educación médica, 10(47). https://doi.org/10.22201/facmed.20075057e.2020.35.20230

Vera-Marquez, A., Olaya, A. \& Denegri, J. (2019) Collaborative International Online Learning: Una experiencia en asignaturas sobre Psicología de la Educación. Reflexiones pedagógicas U Rosario, 18. Retrieved from: https://repository.urosario.edu.co/bitstream/handle/10336/19949/Reflexiones\%20Web.pdf?sequence= $1 \&$ isAllowed $=\mathrm{y}$ 
Veliz-Rojas, L., Bianchetti-Saavedra, A. \& Silva-Fernández, M. (2019). Competencias interculturales en la atención primaria de salud: un desafío para la educación superior frente a contextos de diversidad cultural. Cuadernos de Salud Pública, 35(1). https://doi.org/10.1590/0102-311X00120818 